\title{
PENGARUH STRATEGI PEMBELAJARAN AKTIF TIPE THE POWER OF TWO TERHADAP PRESTASI AKADEMIK MAHASISWA PADA MATA KULIAH MICROTEACHING
}

\author{
Hasan Saragih, Sri Rahmah Dewi Saragih, Fitriani Lubis, Dewi Endriani \\ email : \\ ahasansaragih@gmail.com, dewiendriani80@gmail.com, saragihsrirahmahdewi@gmail.com, \\ rianiavandi@gmail.com
}

\begin{abstract}
Abstrak
Penelitian ini bertujuan mengetahui prestasi mahasiswa penggunaan strategi pembelajaran aktif tipe the power of two pada mata kuliah microteaching Tahun akademik 2017/2018. Sampel dalam penelitian ini diambil dengan menggunakan teknik Cluster Random Sampling yaitu pada penelitian ini adalah mahasiswasemesterVIIA sebagai kelas eksperimen dan VIIB sebagai kelas kontrol dan jumlah setiap semester adalah 30 mahasiswa. Jenis penelitian yang digunakan pada penelitian ini adalah quasi eksperimen (eksperimen semu) dan menggunakan tes yang berbentuk uraian 5 soal. Dari hasil perhitungan pretes dan protes, data tersebut diuji kedalam pengujian normalitas dan homogenitas dari kedua kelas, dinyatakan berdistribusi normal dan homogen. Selanjutnya dilakukan pengujian hipotesis diperoleh $t_{\text {hitung }}=4,53$ dan $t_{\text {tabel }}=2,002$ dengan $d k=30+30-2=$ 58 dan $\alpha=0,05$ maka $t_{\text {hitung }}>t_{\text {tabel }}$ yaitu 4,53 > 2,002, sehingga hipotesis nol ditolak,sekaligus menerima hipotesis alternatif. Sehingga dapat disimpulkan bahwa adapengaruh strategi pembelajaran aktif tipe The Power Of Two terhadap prestasi akademik mahasiswa pada mata kuliah microteaching.
\end{abstract}

Kata kunci:The Power Of Two, Prestasi Akademik Mahasiswa

\section{Pendahuluan}

Pendidikan sangat diperlukan oleh setiap individu maupun masyarakat luas. Salah satu komponen dalam pendidikan adalah pelaksanaan proses pembelajaran. Proses pembelajaran ini mencakup beberapa mata kuliah yang akan diajarkan dosen kepada mahasiswa sesuai dengan bidang keahliaannya. Salah satu mata kuliah yang diajarkan di kampus adalah mata kuliah microteaching.

Microteaching merupakan salah satu mata kuliah yang di pelajari mahasiswa pada jenjang pendidikan tinggi, sebagai salah satu mata kuliah bersyarat yang aplikasinya berkaitan erat terhadap mahasiswa yang cenderung dilatarbelangi sebagai calon guru di dunia pendidikan.Mengingat begitu pentingnya peranan microteaching,maka sudah selayaknya pembelajaran microteaching menjadi bahan pemikiran bagi semua pihak.Tidak hanya bagi dosen, namun masyarakat maupun pemerintah juga berperan penting untuk membantu kualitas pembelajaran guru dalam bentuk simulasi 
microteaching.Kerja sama dari semua pihak diharapkan membantu dalam pencapaian hasil akademik yang baik. Untuk memperoleh hasil yang baik maka diperlukan proses yang baik pula.

Penyelenggaraan pembelajaran microteaching tidaklah mudah karena fakta menunjukkan bahwa para mahasiswa mengalami kesulitan dalam mempraktekan sintaks pelaksanaan microteaching. Selain itu, apa yang dipikirkan mahasiswakebanyakan ketika mendengar mata kuliah microteaching tidak seindah apa yang dipikirkan para pecinta pendidikan. Sebagian dari mahasiswa beranggapan mata kuliah microteaching adalah mata kuliah yang sulit dan menakutkan.

Dosen sebagai pendukung keberhasilan mahasiswa dalam memperoleh prestasi akademik haruslah mampu menggunakan strategi pembelajaran yang tepat dan efektif.Namun kenyataannya dosen masih sering menerapkan pembelajaran yang monoton di awal pembelajaran, sehingga strategi pembelajaran yang digunakan dosen kurang efektif.Dimana dosen bersifat aktif yaitu menerangkan materi dan memberikan contoh.Sementara mahasiswa besifat pasif yaitu mahasiswa secara individu (sendiri) hanya mendengarkan, mencatat, dan mengerjakan latihan soal yang diberikan oleh dosen. Akibatnya mahasiswa secara individu (sendiri) kurang aktif dalam mengikuti proses pembelajaran yang sedang berlangsung di kelas.

Berdasarkan observasi di FKIP Universitas Asahan menunjukkan bahwa hasil akademik mahasiswa yang mengikuti program Magang III belum mencapai hasil yang maksimal sesuai dengan yang diharapkan. Dari perbandingan nilai rata-rata keberhasilan mahasiswa mengikuti program magamg III dua tahun terakhir dari tahun 2015 sampai dengan tahun 2016 nilai microteaching yang diberikan pamong dari mahasiswa masing-masing sangat jauh lebih rendah dari yang diharapkan.

Oleh karena itu, peneliti menawarkan strategi pembelajaran yang dapat digunakan untuk meningkatkan keaktifan dan hasil akademik maahsiswa ketika mengikuti teori-teori dalam pembelajaran microteaching yaitu strategi pembelajaran aktif tipe the Power of Two atau juga biasa disebut dengan kekuatan berdua.Strategi pembelajaran aktif tipe the Power of Two berarti menggabungkan kekuatan dua orang.Menggabungkan dua orang dalam hal ini terbentuk kelompok kecil, yaitu masing - masing mahasiswa berpasangan.Kegiatan pembelajaran ini dilakukan agar memunculkan sinergi bahwa dua orang lebih baik dari pada satu orang dalam mempelajari teoridan praktek microteaching.

Strategi pembelajaran the Power of Two termasuk pada strategi pembelajaran aktif.Pada strategi ini mahasiswa diberikan pembelajaran melalui pertanyaan yang diajukan oleh dosen.Dengan adanya pertanyaan, mahasiswa mendiskusikan pertanyaan dari dosen bersama pasangan kelompoknya. Dengan adanya diskusi mahasiswaakan mampu mengingat materi yang mereka pelajari dan berimbas pada meningkatnya hasil akademik mahasiswa. Karena apabila mahasiswa pasif dan hanya menerima dari dosen, ada kecenderungan mahasiswaakan cepat melupakan apa yang telah dipelajari.

Penelitian ini dilakukan bertujuan untuk Mengetahui apakah ada pengaruh Strategi Pembelajaran Aktif TipeThe Power Of Two Terhadap prestasi akademik mahasiswa Pada Mata kuliah microteaching di FKIP universitas Asahanti T.A 2017/2018.

\section{Metode}

Penelitian ini dilakukandi semesterVII semester ganjil Tahun Akademik 2017/2018. Populasi sebanyak 3 kelas dan sampel yang akan diambil dalam penelitian ini adalah 
semesterVIIA sebagai kelas eksperimen yang akan digunakan Strategi Pembelajaran Aktif TipeThe Power Of Twodan VIIB sebagai kelas control dengan metode pembelajaran langsung. Jenis penelitian ini yaitu quasi eksperimen(eksperimen semu). Instrumen penelitian ini terdiri dari beberapa prosedur.Sebelum melakukan pengajaran dirancang pembuatan Rencana Pelaksanaan Pengajaran (RPP). Instrumen yaitu Pretest diberikan untuk mengetahui tingkat kemampuan mahasiswa dalam sebelum mengikuti pembelajaran microteaching dan Posttest dilakukan untuk mengukur kemampuan mahasiswa setelah tindakan diberikan. Kemudian data yang diambil dari test ini dibandingkan dan dianalisis. Setelah diberikan postest, semua hasil pekerjaan mahasiswa dinilai. Alat pengumpulan data yaitu Tespenilaian microteaching yaitu tes berbentuk tes essay yang terdiri dari 5 butir soal.Materi soal diambil dari materi teori tentang kompetensi microteaching.Sebelum pedoman tes yang berupa soal-soal tes tertulis berupa uraianini digunakan, terlebih dahulu peneliti menguji coba untuk memastikan validitas, reliabilitas, daya pembeda dan tingkat kesukaran.UjiRealibilitas,menggunakan rumus $r_{11}$. Dengan berkonsultasi

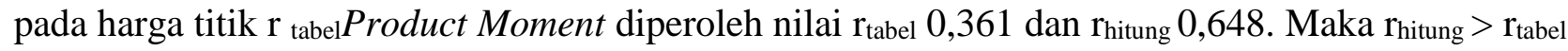
dengan nilai $0.648>0,361$, tes prestasi akademik kedua materi yang digunakan Reliabilitas.Analisa data yaitu Menentukan Nilai Rata-Rata dan Simpangan Baku, Uji normalitas,Uji Homogenitas Varian . Uji homogenitas varians menggunakan uji F.Uji t dua pihak digunakan untuk mengetahui kesamaan kemampuan awal mahasiswa pada kedua kelompok sampel. Hipotesis yang diuji berbentuk $: \mathrm{H}_{0}: \mu_{1}<\mu_{2}$ : Kemampuan awal mahasiswa pada kelas eksperimen sama dengan kemampuan awal mahasiswa pada kelas kontrol. $\mathrm{H}_{\mathrm{a}}: \mu_{1}>\mu_{2}$

Kemampuan awal mahasiswa pada kelas eksperimen tidak sama dengan kemampuan awal mahasiswa pada semester control. Kriteria pengujian adalah :Kriteria $\mathrm{H}_{0}$ jika $-\mathrm{t}_{1-1 / 2} \propto<\mathrm{t}<\mathrm{t}_{1-1 / 2} \propto$ dimana $_{1-1 / 2} \propto$ didapat dari daftar distribusi $\mathrm{t}$ dengan $\mathrm{dk}=\mathrm{n}_{1}+\mathrm{n}_{2}-2$ dan $\propto=0,05$. Untuk harga $\mathrm{t}$ lainnya $\mathrm{H}_{0}$ ditolak.Jika analisis data menunjukan bahwa ${ }_{1-t_{1-1 / 2}} \propto<\mathrm{t}<\mathrm{t}_{1-1 / 2} \propto$, maka hipotesis $\mathrm{H}_{0}$ ditolak, berarti kemampuan awal mahasiswa pada kelas eksperimen. Dan jika analisis datamenunjukan harga $\mathrm{t}$ yang lain, $\mathrm{makaH}_{0}$ ditolak dan $\mathrm{H}_{\mathrm{a}}$ diterima. HipotesisUji t satu pihak digunakan untuk mengetahui pengaruh dari suatu perlakukan yaitu Strategi Pembelajaran Aktif TipeThe Power Of Two. Terhadap Prestasi akademik Matematika yang diuji berbentuk $: \mathrm{H}_{0}: \mu_{1}<\mu_{2}$ : Tidak Terdapat Pengaruh Signifikan Prestasi akademikMahasiswa Menggunakan Strategi Pembelajaran Aktif Tipe The Power Of Two. $\mathrm{H}_{\mathrm{a}}: \mu_{1}>\mu_{2}$ : Terdapat Pengaruh Signifikan Prestasi akademikMahasiswa Menggunakan Strategi Pembelajaran Aktif Tipe The Power Of Two.

\section{Hasil dan Pembahasan}

FKIP Universitas Asahan rombel untuk semester VII sedangkan sampel penelitian sebanyak 60mahasiswa, yaitu semesterVIIA dan VIIB sebanyak masing-masing 30mahasiswa. Ada dua test yang digunakan dalam penelitian, test sebelum pembelajaran (Pretes) dan sesudah pembelajaran (Protes). Test digunakan untuk mengetahui kemapuan mahasiswa dalam materi kompetensi microteaching berupa test essay sebanyak 5 soal. Tes ini sebelumnya sudah diujikan validitas, realibilitas, daya pembeda dan tingkat kesukaran. Pada semester sampel yaitu mahasiswasemesterVIIA sebagai kelas eksperimen yang diajar dengan Strategi Pembelajaran Aktif Tipe "The Power Of Two" dan semesterVIIB sebagai kelas kontrol yang diajar dengan 
menggunakan metode pembelajaran langsung. Hasil penelitian dari nilai pretes sebelum menggunakan model pembelajaran dari kedua kelas tersebut nyatakan test awal sama.

Dari daftrar data nilai rata-rata kelas eksperimen62,4 dan nilai kelas kontrol rata-rata 63,7. distribusi t untuk $\alpha=0.05, \mathrm{dk}=30+30-2=58$. Untuk $\mathrm{dk}=60$ dan $\alpha=0.05$, didapat $\mathrm{t}_{(1-1 / 2 \alpha)(58)}=$ $\mathrm{t}_{(0.975)(58)}=2,002$ dan $t_{\text {hitung }}$ bernilai $-0,33$. Karena $t_{\text {hitung }}<t_{\text {tabel }}(-0,33<2,002)$, maka $H_{0}$ diterima $H_{a}$ ditolak dengan kata lain bahwa kemampuan awal mahasiswa pada kelas eksperimen sama dengan kemampuan awal mahasiswa pada kelas kontrol pada mata kuliah microteaching.

Kemudian kembali dites hipotesis pada akhir pembelajaran (post tes) sesudah menggunakan Strategi Pembelajaran Aktif Tipe “The Power Of Two". Dengan nilai rata-rata kelas eksperimen 80,2 dan nilai rata-rata kelas kontrol63,9, dari daftrar distribusi t untuk $\alpha=0.05$ dan $\mathrm{dk}=30+30-2$ $=58$. Untuk $\mathrm{dk}=58$ dan $\alpha=0.05$, didapat $\mathrm{t}_{(1-1 / 2 \alpha)(58)}=\mathrm{t}_{(0.975)(58)}=2,002$, dan hasil dari thitung adalah 4,53. Maka disimpulkan $t_{\text {hitung }}>t_{\text {tabel }}$ yaitu 4,53>2,002 maka $H_{0}$ ditolak $H_{a}$ diterima. Dalam hal ini dapat disimpulkan bahwa adapengaruh strategi pembelajaran aktif tipe"The Power Of Two" terhadap prestasi akademik matematika mahasiswa pada materi kompetensi microteaching di semesterVII FKIP Universitas Asahan T.A 2017/2018.

Setelah diketahui dari sesudah mennggunakan strategi pembelajaran aktif tipe"The Power Of Two "terhadap prestasi akademik matematika mahasiswa. Sehingga dapat disimpulkan bahwa strategi pembelajaran aktif tipe "The Power Of Two" mampu mempengaruhi meningkatnya prestasi akademik matematika mahasiswa sehingga semua mahasiswa mencapai kompetensi microteaching.

\section{Kesimpulan}

Berdasarkan hasil penelitian data, pengujian hipotesis dan pembahasan penelitian maka dapat disimpulkan bahwa.Berdasarkan hasil penelitian, tes yang akan diujikan sebelumnya untuk mengetahui soal tes yang akan digunakan secara efektif dan efisien yakni di uji validitas, tes tes realibilitas, tes daya pembeda dan tes tingkat kesukaran. Pada awal pembelajaran (pretest) kelas eksperimen dan kelas kontrol diberikan pemahaman materi yakni kompetensi microteaching sebelum tindakkan dilakukan, kemudian hasil pretest dijadikan sebagai awal data untuk pertimbangan penelitian.

Pada data awal (pretest) pembelajaran kedua semester sebelum menggunakan Strategi Pembelajaran Aktif TipeThe Power Of Two diujikan kedalam uji normalitas dan uji homegenitas dinyatakan data tersebut normalitas dan homegenitas. Hasil data awal pembelajaran diuji kedalam uji t dua pihak untuk mengetahui apakah ada perbedaan pada awal pembelajaran dikelas eksperimen dan semester kontol pada pemahaman materi kompetensi microteaching, dinyatakan $\mathrm{H}_{0}$ diterima , $\mathrm{H}_{\mathrm{a}}$ ditolak dengan kata lain bahwa kemampuan awal mahasiswa pada kelas eksperimen sama dengan kemampuan awal mahasiswa pada kelas kontrol pada materi kompetensi microteaching.

Kemudian di tes hipotesis kembali pada akhir pembelajaran (postes) sesudah menggunakan Strategi Pembelajaran Aktif Tipe The Power Of Two,hasil data diujikan kedalam uji normalitas dan uji homegenitas dinyatakan data tersebut normalitas dan homegenitas, kemudian diuji kedalam uji t dua pihak dinyatakan $\mathrm{H}_{0}$ ditolak $\mathrm{H}_{\mathrm{a}}$ diterima, dengan kata lain bahwa Ada pengaruh Strategi Pembelajaran Aktif Tipe The Power Of TwoTerhadap Prestasi akademik Matematika Mahasiswa Pada Materi kompetensi microteaching Di Semester VII FKIP universitas asahan T.A 2017/2018. 


\section{Daftar Rujukan}

Arikunto, Suharsimi. 2012. Dasar - Dasar Evaluasi Pendidikan. Jakarta: PT Bumi Aksara.

Hamruni. 2012. Strategi Pembelajaran. Yogyakarta : Insan Madani.

Sudjana. 2015. Metoda Statistika. Bandung: PT Tarsito.

Sugiyono. 2014. Metode Penelitian Administrasi. Bandung : Alfabeta.

Sukardi. 2013. Metodologi Penelitian Pendidikan. Yogyakarta : PT Bumi Aksara.

Sukmawarti.2012.Evaluasi Proses dan Hasil Pembelajaran Matematika.Medan : Prodi Pendidikan Matematika Fakultas Kedosenan dan Ilmu Pendidikan.

Suprijono, Agus. 2010. Cooperative Learning. Surabaya: Pustaka Pelajar.

Trianto.2009. Mendesain Model Pembelajaran Inovatif-Progresif.Surabaya: Kencana Prenada Media Group. 